\title{
Black: A persuasive metaphor in Guinness stout's advertisements in Nigeria
}

Taofeek Olaiwola Dalamu

University fo Lagos (Nigeria) 



\title{
Black: A persuasive metaphor in Guinness stout's advertisements in Nigeria
}

\section{Negro: una metáfora persuasiva en los anuncios de Guinness stout en Nigeria}

\author{
Taofeek Olaiwola Dalamu \\ University fo Lagos (Nigeria) \\ lifegaters@yahoo.com
}

Fecha de entrega: 26 de febrero de 2018

Fecha de aceptación: 26 de mayo de 2020

\begin{abstract}
This study investigated the terminology of Black as a metaphor that promoted the image of Guinness ${ }^{\circledR}$. Thus, six advertisements of Guinness, deploying Black as the hub, were selected for illustrations. The author adopted the concept of career metaphor supported with the Halliday's mood system for the analysis. As Guinness embraced qualities of Black as its stronghold-cum-primary source domain, the study revealed the model, as a paradox, evoking African-American identities upon Africans. Black attributes, as being fashionable, beautiful, sophisticated, independent and unique, facilitated readers to consumption by seducing the audience to perceive Guinness as admirable personified Black. People can no more consider Black as a derogatory color concept, being a coinage of colonial mastery. It is exalted as an important object of identification that sponsors the globally-renowned Guinness. The study suggested that researchers should not perceive Black as only synonymous to Guinness, but should serve as an approach to communicate self-worth lifestyle of distinctions.
\end{abstract}

Keywords: Advertising representation; Black of Guinness; Interpersonal Metafunction; Metaphor

\section{Resumen}

Este estudio se centra en el uso del término Black como una metáfora de la imagen de Guinness ${ }^{\circledR}$. De esta forma, seis anuncios de Guinness utilizan la idea de Black como imagen de sus campañas publicitarias. El autor emplea el concepto de metáfora desarrollado por Lakoff y Johnson apoyado por el sistema tripartito de Halliday. A medida que Guinness adopta las cualidades de Black como su dominio fuente de fortaleza-primaria, el estudio reveló que el modelo es muy distinto. 
Black: A persuasive metaphor in Guinness stout's ...- T. Olaiwola Dalamu

Los atributos de "negros", como sinónimos de elegantes, hermosos, sofisticados, reales, famosos, etc., facilitan el consumo de los lectores seduciendo al público que percibe a Guinness como un negro personificado que debe ser admirado. El "negro" ya no es un concepto de color despectivo invención del dominio colonial. Es exaltado como un importante objeto de identificación que patrocina a Guinness, de renombre mundial. El estudio sugirió que los investigadores no deberían percibir a Black solo como un sinónimo de Guinness, sino que debería servir como un enfoque para influir en sus elecciones y estilos de comunicación.

Palabras clave: Representación publicitaria; "Negro" de Guinness; Metafunción interpersonal; Metáfora.

\section{INTRODUCTION}

One could remark that the language of man in his surroundings contains and caters for some metaphorical imaginations. Such deployment in social interactions communicates deep thoughts from one man to another. Metaphorical facilities convey meanings which are not in any way haphazard, but rather their meaning potentiality is based on the socio-cultural nerves of the interactants (Koschick, 1995; Rosenberg, 1995; Hermerén, 2001; Forceville, 2005; Wierzbicka, 2006). In one way or another, that context has made human linguistic functions to be motivated in metaphorical applications in a daily basis. Upon this background, copywriters utilize some of the metaphorical expressions to influence the decision of their audience in order to facilitate consumption of products. Kovecses recognizes this when he argues that;

Major manifestations of conceptual metaphors are advertisements. Part of the selling power of an advertisement depends on how well chosen the conceptual metaphor is that the picture and the word used in advertisement attempt to evoke people. An appropriately selected metaphor may work wonders in promoting the sale of an item (Kovecses, 2010, p. 65).

Metaphor commodifies objects in the realm of persuasion (Goldman, 1992). Advertising employs metaphor, Kovecses (2010) asserts, to convince the target audience in a rational way. The construction of metaphor compels consumers to begin to embark on semantic exercise of decoding the meaning probability of the created concept. This becomes possible, most especially, when the text connects the cultural treasures of the people. Metaphor that manifests the culture of the people in the form of association and representation seems to appeal adequately to the public (Brierley, 2002; El Refaie, 2009; Forceville, 2013).

Perhaps, the initiation of representation is a cultural phenomenon in the advertising world. The idea of modeling a thought, desiring a particular reality is a strategic means of disguise. This is because writers usually avoid message monotony by all means (Wicke, 1988; Myers, 1986). This is a reason that the notion of 
representationalism comes to the lime light (Batra, Myers \& Aaker, 1995; Howard, 2012). Advertising practitioners might not want to present their products literally in a common way at all times. Advertisers tend to hide under a particular guise of reality to realize their persuasive dreams. Persuasion in advertising is not a rigid concept, rather constructed in the best manner in order to be influential. Chandler (2006) explains that representation is the construction in a medium of aspects of reality. The reality could be people, places, objects, or any socio-cultural entity. In that sense, representation has no limit, operating in a free world of any entity to produce meanings. In support of Chandler's thought, Tomaskas (2014) states that the representation of reality could be viewed from two perspectives of the process and the product. When a writer constructs an ideal reality, the individual expects the target audience to interpret the determinate set of meanings (Nixon, 1996), inculcated in the modeled image.

Sometimes, a writer conceptualizes the framed object with common ideological reality in a social circle. The 'framer' usually adopts the objects that the target audience is familiarized with for proper understanding. There is an intention to build correlating relationships between the reality and the idea that the communication represents. As such, metaphorical objects in ads are commonalities with deep meaning (Stern, 2008), with critical interpretations, attracting consumers' attentions.

Advertising, as a broad term-cum-discipline, has received appreciations from different perspectives of literature, psychology, communication, sociology, economics (Harris \& Seldon, 1962; Geis, 1982; Gee, 2011; Dyer, 2005) and other social sciences (Schultz \& Barnes, 1995; Massaris, 1997). Linguists have also contributed en masse to the analysis of advertising. In that regard, Leech (1966) investigates texts of advertisements (henceforth: ads) as communications take a course in Great Britain, while Tanaka (1994) explores, in pragmatic forms, some ads of Great Britain and Japan. The works of Myers (1994), Geiszinger (2001), and Cook (2001), among others, rest on rhetorics, puns as well as quantitative offerings. Particularly, there are studies exemplifying series of metaphors in advertising (Forceville, 2000 \& 2006). Besides, Maalej (2001) and Kovecses (2005) examine cultural but pictorial metaphors, whereas, El Refaie (2003), and Bounegru and Forceville (2011) provide readers understanding of metaphors of cartoons in various communication domains.

Of significance are Ricoeur (1977), Forceville's (2007), and Kress' (2010) illuminations on metaphor as discourse and multimodal metaphors, anchored on cultural backgrounds of recipients As Honeck (1996) and Imre (2010) provide historical accounts of contributors of metaphor, Forceville (1996) explains personal similes in ads, encircled with metaphors. The focuses of Martín de la Rosa (2009) and Svaziene (2010) are on the effectiveness of verbal, non-verbal and persuasive metaphors on readers. These studies are not only westernized, the arguments 
have not focused on a single terminology as the current endeavor has perceived representational thought, Black, in the 2014 Guinness ads in Nigeria.

This is on the ground that Black does not only a compelling choice that foregrounds the textual elements; the concept also is a phenomenal African-American identity. The analyst considers the 'B' of Black in the upper case because of its utmost importance to the study, viewing Black as a concept of a human characteristic. Black is a probable captivation because of the variegated thoughts that people may have about its effects on human mental perceptions. This approach expounds the adoption of Black as a metaphorical reality of persuasion in the Guinness ads. The aim is to demonstrate the effects of Black on the ad message and how this metaphor is stylized in each clause, evoking African-American cultural qualities on Nigerians in Africa. This can motivate writers and researchers to create particular style of communication for individuals and the target audience. The interdisciplinary nature of the study in linguistics, cognitive science, culture studies and advertising propels the author to adopt career metaphor, Black consciousness movements and Systemic Functional Linguistics (SFL) as analytical-explanatory paradigms, making the study scientific.

\section{LITERATURE REVIEW}

\subsection{The concept of black}

There are some distinctions in which the study appreciates Black. It regards Black as the darkest among the color regiments available in the world. Besides, Black is an element that depicts a shady deal or a bad attribute, where openness becomes an aberration. Another profound notion of Black is that the term exemplifies a human group that has 'dark skin', most of them Africans. Depicting a class of people with the notion of Black is pejorative because the skins of Africans are not really black. Sometimes ago, in retrospect, some individuals differentiated one race from another. The concept Black (or White) subjectively-arbitrarily became customary to represent the human race. As long as representing a race as Black has been phenomenal from the inception, whatever the label suggests, abides till now without unremarkable changes. Consequently, one could comment that it is too late for anyone to contest the sustainability of the derogatory remark. That seems a probable motive for Livingston, Pierce and Gollop-Brown (2013) to argue that 'Cultural and racial selfidentifications can be as complex as they are important' (p. 1). Livingston, Pierce and Gollop-Brown perceive racio-cultural identifications as significant and complex. The classification of things including mankind is a necessity to enhance knowledge. Yet, such endeavor regarding human beings tends to be complex because of the wide-ranging nature of the human race especially in terms of color regimentations. Thus, the categorization of mankind into Black (and White) is alarming, and calls for re-evaluation. 
However, one understands that the colonial masters of the ancient days were looking for a way to conceptualize master-slave relationships, which was achieved through the permanent skin classification. Perhaps, such taxonomy is not actually academic for there is no concrete evidence for the categorization nonetheless it is purely business oriented. It is obvious that there are others in the world whose skins' appearances could not be gauged with these norms. For instance, no one classifies Cambodians and the Arabs into the Black-White dichotomy. If someone may ask: What color are they? in respect of that, Cross, Parham and Helms (1991) argue that it is appropriate when the Black identity model is applied to African-American. However, can we accurately apply the same label to the entire Black persons in the United States? The application of Black might be imprecise for most people who do not appear as White. It does suggest that not all Black people are Africans. The argument is an indicator that no one can automatically characterize human racial norms into Black (and White) (Cross, Parham \& Helms, 1991; Strommer, 2001; and Deutsch, Doberstein \& White, 2008). The individual's racial background seems to influence his attitudes and the way he construes the world around him. The blanket generalization of human race into Black and White, to the author, is inappropriate. The categorization is just a smart way for few people to achieve a particular desire outside the norms of the natural law. In color identification, as one might emphasize, no human skin falls within the standardization of 'black color' or 'white color' when compared to color formations, appearances, and codes in both natural norms and scientific manifestations.

Moreover, the color, Black, displays various meaningful qualities. From the perspective of Psychology, Black color 'relates to hidden, secretive and the unknown, and as a result the terminology creates mystery' (Tomaskas, 2014; www.empoweryourself-with-power-psychology.com). Black, in the perspective of Tomaskas, is a hidden place where some evil things could be subdued. Following Tomaskas (2014), the color properly functions in domains where light is absent. One might require the knowledge of certain degree of sophistication to unravel the contents of Black in any place that it operates. In that wise, Black seems synonymous with darkness such that the features of Black may serve as barriers to certain actions of other objects other than itself. Thus, Black connoting with darkness may prevent the performance of certain activities. Apart from those negative nuances, Churcher's (2009) positive description refers to the concept of Black as overbearing power to control other entities. This is possible because of the fear relativity that the notion creates in human minds. Through this Black appears intimidating because of its domineering dignity. One could also suggest that Black marks the end of a thing and the beginning of another thing. That claim hangs on cultural affiliation, at least in Nigeria, where the concerned individuals wear black dresses in honor of a dead fellow. The black apparel symbolizes the end of a person's era on earth in order to begin another one somewhere else. The belief of individuals determines this. Furthermore, it is intriguing to observe that people do associate Black with sex and seduction. The 
angle of seductive representation of Black seems to be the perspective that the copywriter embraces as integrated in the Guinness ads.

It is worth stressing that negative propagation of Black spackled the Black civil right movement and consciousness movement in the US and South Africa respectively. The dehumanization and derogatory denigration of Black served as a springboard to the Black power movement in the US, having observed that the displaced Africans were culturally cut off from their land of origin (Taylor, 2017). The masters took the Black to a totally novel and hostile Americas, subjugating individuals to alien cultures. Consequently, the slogan Black is beautiful (Pityana, 1972) served as an ideological vehicle of promoting precious qualities of the Black, combating the forces of racism.

Furthermore, the derogatory attitude of the White to the Black became a triggering mechanism to Black consciousness movements. Prominent figures, among others, are Martin Luther King, Malcolm X, Marian Anderson, Bishop Robert Selby Taylor, and Nina Simeon. Specifically, Martin Luther King initiated nonviolent solutions to liberation against bans, sufferings, and prohibitions. The protests germinated and grew in the US, creating self-consciousness, self-actualization and campaigning of Black aesthetics (Malcolm, 1965; Fradkin, 2018). Thus Guinness seemingly became a promoter of Black consciousness; in turn a campaigner of Black is beautiful slogan. This is a channel to persuade the Black audience to drink the Guinness stout. The communication became possible because of the correlation of the stout color with the human label, Black.

Perhaps, that communicative feature motivates Adedun (2006) to argue that the interest of advertising practitioners mostly lies in the materials that can be adopted to persuade the target audience anywhere such can be located. The motive of Guinness for adopting Black, to recap, is to propagate the terminology as a seductive phenomenon as a strategy to the consumption potency of the beer. Black, the metaphorical object, has a probable capacity to provide comfort to Nigerian consumers of Guinness. This study considers that goal as the first reason for the interchangeability conceptualization (Williamson, 2002. This writer could characterize the logic of the persuasion thus: Black = Guinness; Guinness = Black; Black $=$ People People $=$ Black . The summation is that Guinness $=$ People.

\subsection{Conceptual framework}

A combination of a metaphorical view, inclined with the cultural approaches and Halliday's (1985) Interpersonal Metafunction are considerable procedures and explanatory paradigms of the study. This is because the Interpersonal Metafunction has the capacity to analyze text appropriately into their semiotic slots. And metaphor has the strength to provide enough resources for textual and cultural discursive strategies. 


\subsubsection{Metaphor}

Metaphor is a cognitive mechanism that reflects language as a communicative instrument of power to control an event. On that ground, interactants exhibit metaphor to manipulate human minds and decisions in relations to context (Dijk, 2008). The use of metaphor indicates both the knowledge and beauty of a particular cultural heritage, positioning the concept as an object that reflects two divergent elements. The dissimilar features of the objects, Lakoff and Johnson (1980) explicate, are in what the two entities account for. However, the opposing subjects interact in a way that compels the attributes of one to dictate the position of another. Some scholars, including Martín de la Rosa (2009), articulate their views on metaphor to sustain the cognitive impetus of Lakoff and Johnson on the subject. Hence, metaphor represents 'a cognitive device which allows interactants to deal with abstract domains of experience by understanding and experiencing one thing in terms of another' (p. 167). The domain of knowledge of a concept could determine the level of understanding that one has to demonstrate in a metaphorical sense (Glucksberg, 2003). The knowledge of item B (Kovecses, 2010) gives rise to what item B entails, functioning in short-term and long-term spans. Thus, the construal and interpretation of complex metaphorical signals depend largely on the cultural exposure of readers (Forceville, 2008).

The conceptual domains possess contradicting tenets; but the spheres are parallel in semantic values when the characteristics of conceptual domain B are equated in relations to conceptual domain A. In addition to that, Kovecses (2010) labels the two subjects participating in the metaphoric nexus as (i) source domain and (ii) target domain. The source domain is the principal image in which the interactants draw exemplary traits; the target domain is the figure that the traits drawn from the source domain are applied to. For instance, Life is war is a metaphor. Life = Conceptual Domain A and War = Conceptual Domain B. Therefore, War $=$ Source Domain and Life $=$ Target Domain. The communicators draw metaphorical understanding from the target domain in terms of the attributes of the source domain, using one's logical mapping discernment. The negotiators reconcile the differences in the domains by substituting the features that are peculiar to the conceptual domain B for conceptual domain A in a functional context. The target domain and source domain relationships sometimes do not cover their entire boundaries of operation. Notwithstanding, the source domain foregrounds the behavior of the target domain as they amalgamate in communicative partnerships.

The creation of similarities between target domain and source domain coheres through the correlations of social experiences (Black, 1993; Ortony, 1993; Forceville, 1996). On that semantic configuration, the cultural background will initiate the correlating meaning derivatives from the conceptual domain of the metaphors (Forceville, 2017). Ortony (1993) identifies two terms that are paramount in similarity metaphors. He calls the first topic. The second, he calls vehicle. Ortony's topic is 
significantly correlated with Kovecses' target domain, while vehicle is correlated with source domain. Black (1979) principle classifies the metaphorical imagery system into primary subject and secondary subject.

Although, the systematic features of conceptual domain A is similar in construction with that of domain B in a systemic textual affiliation, Imre (2010) says that there are some classificatory limitations. In this restriction model, the target domain may not adopt the tenets of the source domain in its sum. Imre (2010) further suggests that 'we employ only a part of a source domain, and not the whole' (p. 79). To an extent, the target domain does not assume in totality the value of the source domain. For instance, if Bola is a philanderer (or playboy), Bola could be metaphorized as a dog, that is, Bola is a dog. It may turn to be that no one with the knowledge of the community norms in this regard will query the new label of Bola.

From a cultural context, the language users would have readily conceived the meanings surrounding the application of the target domain in terms of the source domain. For instance, a dog has some natural characteristics. Some of these traits (at least, in the Nigerian environment) are: a dog bites; a dog barks; a dog sleeps outside; and a dog does not have logical reasoning that measures up to or correlates the stance of a human being. Furthermore, a dog eats excreta; a dog eats bones; a dog eats from dustbins; a dog practices sex in the open; a dog fights; and a dog is a domestic animal. Others are: a dog has four legs and walks with four legs; a dog picks and eats food with its mouth and a dog can give birth to ten puppies at a go.

The relevance of a dog in Bola's behavior is the unrestricted sexual practices in the open. However, a dog neither has a wife nor a husband. A dog performs unrestricted sexual conducts unlike human beings. A dog enjoys sex with any other dog anywhere, anytime, any-day and anyhow. These natural peculiarities in a dog are not within the scope of human ideological practices. A special case of shameless sexual practices observed in anyone could motivate the subordinates to label the individual as a dog. This is a signal that the context of a metaphorical expression, to a considerable extent, determines its meanings. So, language users could employ the conceptualization of a human being as a dog in so many social variations to convey different meanings. If Bola loves to fight people shamelessly, in that context, Bola is a dog. The source domain, dog, provides readers different interpretation from the previous application of Bola is a dog. The restricted application of the tenets of domain B to domain A is a partial mapping (Imre, 2010; Kovecses, 2010) that considers a metaphor's peak of prominence and relevance only.

The author might suggest that metaphor is creative. Apart from the well-known metaphor in languages, individuals can create metaphors at a particular time for a particular purpose. Sometimes, the conventional application of metaphor provides readers cultural thoughts. Metaphorical creativity dynamically contributes to language development in a considerable degree. Then, a metaphor could become a burden to anyone who is not a member of a particular speech community. This 
is owing to the fact that the individual would not function in the same field of experience with other people, which Bittner (1989, p. 10) exemplifies as homophily. The elements of metaphor are: the target domain (topic, primary subject) and the source domain (vehicle, secondary subject). The study refers to the concepts freely when necessary.

\subsubsection{The Interpersonal metafunction.}

This is one of the Halliday's three functional meanings of Ideational, Textual and Interpersonal Metafunctions. Bloor and Bloor (2004 \& 2013) argue that the Metafunctions are the core values in the Hallidayan SFL. Interpersonal Metafunction describes the relationships between a speaker and a receiver in communication. This comes through what Bloor and Bloor (2013) label as 'interact'. On that note, Halliday explains that there are distinctive factors which explain interpersonal communication. In Halliday's (1985) sense:

The most fundamental types of speech role, which lie behind all the more specific type that we may eventually be able to recognize are just two: (i) giving, and (ii) demanding. Either the speaker is giving something to the listener (a piece of information)... or he is demanding something from him...giving means inviting to receive, and demanding means 'inviting to give'. The speaker is not only doing something himself; he is also requiring something of the listener. Typically, there is an 'act' of speaking... something called 'interact': it is an exchange, in which giving implies receiving and demanding implies giving in response (p. 68).

Halliday and Matthiessen (2004) comment that 'cutting across this basic distinction between giving and demanding is another distinction, equally fundamental, that relates to the nature of the commodity being exchanged. This may be either (a) good - \& - services or (b) information' (p. 107). Halliday's (1985), and Halliday and Matthiessen's (2004) thoughts on clause as exchange have given rise to the four speech functions labeled as; offer, command, statement and question as illustrated in Figure 1 below.

\begin{tabular}{|l|l|l|l|}
\hline Role in exchange & $\begin{array}{l}\text { Commodity exchange } \\
\text { Giving }\end{array}$ & $\begin{array}{l}\text { (a) } \\
\text { Goods-and- services }\end{array}$ & (b) \\
\hline Demanding & Offer & Statement \\
\hline & Command & Question \\
\hline
\end{tabular}

Figure 1: Basic Speech Roles (Thompson, 2004, p. 47) 
Halliday and Matthiessen (2014) submit that in Interpersonal Metafunction, the principal grammatical system is that of MOOD, different from mood in human feelings. The grammatical MOODs match the speech functions - declarative, imperative, interrogative and modulated interrogative (Eggins, 2004). The speech functions demonstrate the participants' contributions in the role relationship goingson. The grammatical MOOD identifies the relevant structure in the system. Thompson (2014) elucidates that the MOOD system is complex, sometimes signaling the subject and finite (Thompson, 2004, p. 49), as demonstrated in Figure 2, below.

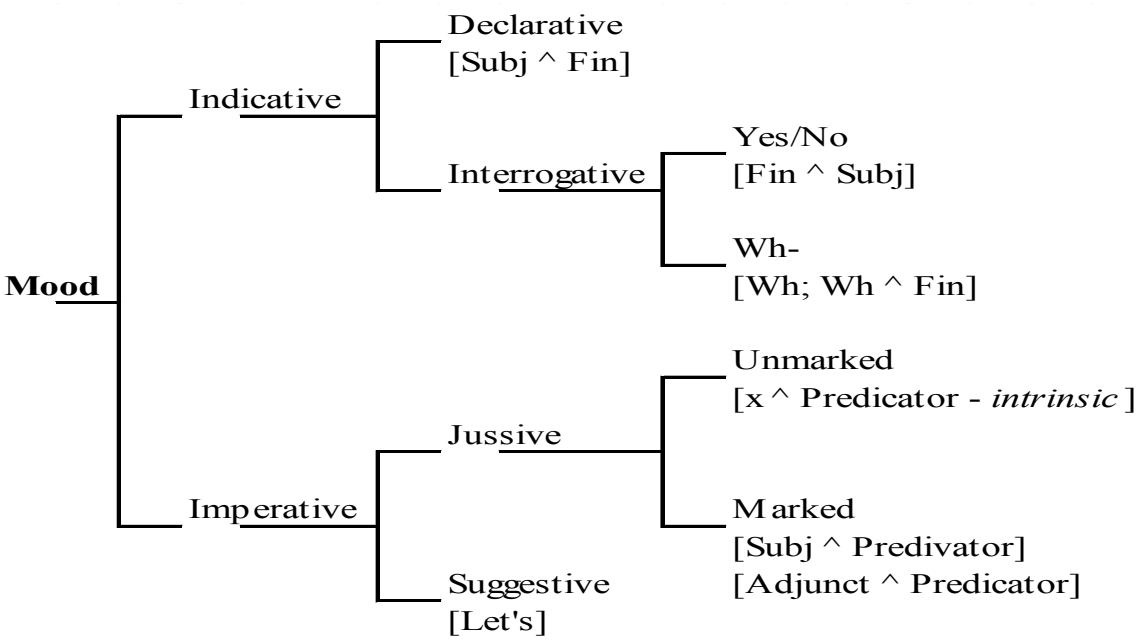

Figure 2: Mood system of English (Thompson, 2004)

In Indicative Clause: MOOD System $=$ Subject + Finite (Subject $\wedge$ Finite) e.g. Kunle is good.

or Finite + Subject (Finite` ${ }^{\wedge}$ Subject) e.g. Is Kunle good?

In Imperative Clause: $\mathrm{MOOD}$ System $=\mathrm{S}^{0}+$ Finite (intrinsic) i.e. 'hangs in the air' e.g. Write it. Thompson (2004) further suggests that it is usually relatively easy to identify the Subject, and only a little less difficult to identify the Finite, but in cases of doubt (at least in declarative clauses) one can establish exactly what the Subject and Finite of any clause are by adding a tag question. From Thompson's (2014) opinion, the Finite is the first functional element among the verbal group. It is most easily recognized in yes/no questions, since it is the auxiliary which comes in front of the Subject. In most cases, the Finite 'fuses' with the lexical verb. 


\section{METHODOLOGY}

\subsection{Participants}

The inspiration for investigating Guinness-Black ads came to the lime light when the researcher travelled on March 2014 from Lagos to Igbesa, Ogun State Nigeria for a function. The author observed Guinness an advertising frame, accommodating a message, Black is not a color; Black is an attitude by the roadside. The observation that Black in the ad is metaphorically contextual motivated the analyst further to go in search of Guinness relevant ads of such communicative degrees. Precisely, in April 25, 2014, the researcher requested the assistance of Mrs. Bonke to accompany him to Ibadan, Oyo State Nigeria in search of similar ads having obtained about seven of such from Lagos. The choice of Bonke relied on her long distance driving capability and her understanding of the parts of the South-West Nigerian cities. In Ibadan, Bonke and I harvested about five relevant Guinness-Black ads for about two days. The researcher compensated Bonke with $\$ 20,000.00$ ( $=$ Nigerian currency) for her contributions to the ads' materials collection processes. The Punch newspaper and the Internet were other domains where the researcher collected twelve Guinness ads. The similarities influenced and limited the number of the ads collected altogether - the population of 24 ads.

\subsection{Instruments}

The camera, WB50F of Samsung ${ }^{\circledR}$ brand assisted the investigator in capturing the ads from their frames both in the signposts and pages of the Punch newspaper. An

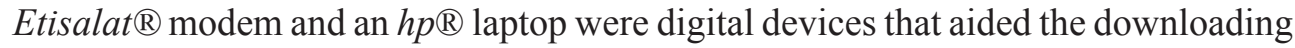
of some Guinness-Black ads from the Internet.

\subsection{Design and procedures}

The researcher stratified the twenty-four ads, serving as the population into four segments in which the selection of six ads were made. The commonalities considered for the design and selection were on the types of images and texts in the frames. The target audience addressed and the entire organization of the components in the frames also informed the selection scores of the samples. The study presented below the six ads as the subject of analysis with nesting '//' which functions as the clause traditional demarcation sign of SFL. The study labels the clauses of the ads as Txs.1, 2, 3, 4, 5 and 6. The Interpersonal Metafunction remains the theoretical task for textual analysis and metaphor for the explication of literal and figurative items. 
For value identification and textual accountability, the study utilizes table and graph which are technological tools. The discussions accompany the ad frames so that each text can be visible to the audience for purposes of clarity and easy accessibility. Apart from the metaphorical concept of the target and source domains, significantly, the analyst sometimes describes the ads with the African-American cultural appraisal. There are other textual elements in the Guinness advertising plates; the study does not consider devices that are not directly relevant to Black, as a metaphor. In other words, the researcher gives credence to only textual contents creating relationships between Black and Guinness.

\subsection{Data presentation}

Texts 1, 2 to 6 represent the constructs, considered in the Guinness ads.

Tx.1//Black celebrates//

Tx.2 //Black dances to a different beat//

Tx.3 //Black writes its own rules//

Tx.4 //Black is not a color; black is an attitude//

Tx.5 //Black is beautiful//

Tx.6 //Black got swag//

\subsection{Data analysis}

Figure 3, below, displays the application of Halliday's (1985) MOOD to the Guinness ads' texts. 
$\underline{\text { Revista de Humanidades, } 40 \text { (2020). p.37-68. ISSN 1130-5029 }}$

\begin{tabular}{|l|l|l|}
\hline Tx.1 & Black & celebrates \\
\hline Subject & Finite:Present & Predicator:celebrate \\
\hline Mood & Residue \\
\hline
\end{tabular}

\begin{tabular}{|l|l|l|l|l|}
\hline Tx.2 & Black & dances & to a different beat \\
\hline Subject & Finite:Present & Predicator:dance & Adjunct \\
\hline Mood & Residue & \\
\hline
\end{tabular}

\begin{tabular}{|l|l|l|l|}
\hline Tx.3 & Black & writes & its own rules \\
\hline Subject & Finite:Present & Predicator:write & Complement \\
\hline Mood & Residue & \\
\hline
\end{tabular}

\begin{tabular}{|c|c|c|c|c|c|}
\hline Black & is not & a colour & \multirow{2}{*}{\begin{tabular}{|l} 
Black \\
Subiect
\end{tabular}} & \multirow{2}{*}{$\begin{array}{l}\text { is } \\
\text { Finite }\end{array}$} & \multirow{2}{*}{\begin{tabular}{|l} 
an attitude \\
Complement
\end{tabular}} \\
\hline Subject & Finite & Complement & & & \\
\hline Mood & & Residue & Mood & & Residue \\
\hline
\end{tabular}

\begin{tabular}{l|l|l|l|}
\hline Tx.5 & Black & is & beautiful \\
\hline Subject & Finite & Complement \\
\hline Mood & Residue \\
\hline
\end{tabular}

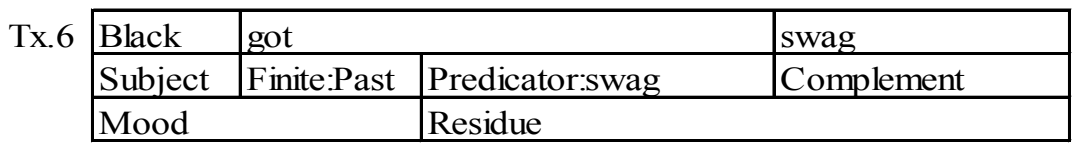

Figure 3: Textual analysis of Guinness ads

\subsection{Results}

The study translates analysis in Figure 3 into table and graph in Table 1 and Figure 4 respectively for value deductions.

\begin{tabular}{|l|l|l|l|l|l|l|l|}
\hline $\begin{array}{l}\text { Mood } \\
\text { Resource }\end{array}$ & $\mathrm{Tx} 1$ & $\mathrm{Tx} 2$ & $\mathrm{Tx} 3$ & $\mathrm{Tx} 4$ & $\mathrm{Tx} 5$ & $\mathrm{Tx} 6$ & Total \\
\hline Subject & 1 & 1 & 1 & 2 & 1 & 1 & 7 \\
\hline Finite & 1 & 1 & 1 & 2 & 1 & 1 & 7 \\
\hline Predicator & 0 & 1 & 1 & 0 & 0 & 1 & 3 \\
\hline Complement & 0 & 0 & 1 & 2 & 1 & 1 & 5 \\
\hline Adjunct & 0 & 1 & 0 & 0 & 0 & 0 & 1 \\
\hline
\end{tabular}

Table 1: Recurrence of mood elements 
Figure 4, below, illustrates the cumulative frequencies of the communicative devices, as represented in Table 1, below.

\begin{tabular}{|l|l|}
\hline $\begin{array}{l}\text { Mood } \\
\text { Resource }\end{array}$ & Total \\
\hline Subject & 7 \\
\hline Finite & 7 \\
\hline Predicator & 3 \\
\hline Complement & 5 \\
\hline Adjunct & 1 \\
\hline
\end{tabular}

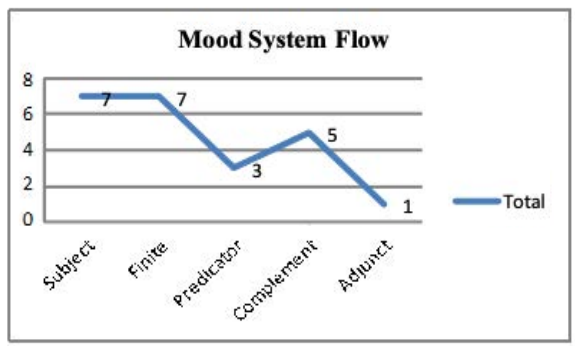

Figure 4: Mood system appreciation on the texts

Subject and Finite are the common structural elements to all the texts in the ads as shown in Figure 4. These linguistic components signal that the copywriters only provide impressive statements to the public about the Guinness product. Complement and Predicator shift grounds once in a while to actualize the intended message. However, only Tx. 2 utilizes Adjunct in the constituents. These values demonstrate the strength at which Guinness organizes other structures along with the concept of Black to achieve persuasion. The deployment of Subject and Finite is very unlikely in most ads (Dalamu, 2018); rather most ads seemingly command the audience to buy a good or service (Myers, 1994). Ads exercise their strengths in disjunctive structures. An explanation for the structural consistency of Subject and Finite is that texts are deployed as devices of representation with paradigmatic alternatives leaving Black, the Subject to function at the peak of prominence.

\section{DISCUSSION}

Black is the central item of the text in Guinness stout ads. In that regard, the analyst replicates the discussion from two perspectives. The first approach elicits advertising items from a linguistic perspective, offering a systematic metaphorical thought on the wordings of the frameworks (Kovecses, 2010). The second sphere elucidates the metaphor of black from cultural idea, as strongly emanated from African-American perspective of the concept of Black is beautiful concept in the 1960s (Gayle, 1971; Snail, 2008).

From a technical scientific viewpoint, one observes the notion of Black in all the texts as the literal item A, which is the target domain. Black, the conceptual domain A operates in a paradigmatic format (a kind of constant choice) to several conceptual regions as appeared in the entire ads. As a result, the textual queue begins first and 
foremost with Black with other linguistic elements following it. In the syntagmatic structural linearity, the choice, Black, functions at the thematic position before the residue operates. It is a thought of lumping the Textual Metafunction with the Interpersonal Metafunction of the systemic idea. In a simple term, the author could suggest that Black is a choice that accommodates other linguistic choices in the structures. It means that Black is constant and an irresistible choice that begins each of the clauses with replaceable chain of structures in the ads. In another height, one could likened Black to a magnetic element that attracts attention of other residues in the clauses or sentences. The writer further observes that Black is structured as an incontestable component that, in a chameleonic method, changes its textual apparels in the ads to indicate novel semantic explications. That alternation introduces and integrates new meanings into the concept of Black. In that capacity, this metaphor foregrounds the entire texts one after another. The unrepentant deployment of Black could have been monotonous in functional appearance, however, that has been obliterated by engaging itself in the 'textual-inter-racial interlock of different source domains. In that light, Black is 'a' covetous domain that is not satisfied with romancing itself with a source domain. It rather sustains ephemeral relationships. This behavior points to both structural and semantic commercialization of Black.

The advertiser describes Guinness in the thoughts of Black. As mentioned earlier, in a reciprocating model, Black is Guinness; Guinness is Black. One might clarify that the common denominator exemplified in $B L A C K$ and GUINNESS is COLOR extrapolation. Notwithstanding other characteristics of Black and Guinness, the two entities share color as their high-salient element. The color correlation serves as their 'wedding ring.' Because the advertisers have failed to explain to observers, analysts and the entire audience whether it is Black that is Guinness, or Guinness that is Black; compellingly, every reader has been involved in the critical exercise of applying the constructs as either Black is Guinness or Guinness is Black respectively. By implication, Black and Guinness enjoy common and contextual qualities. This is, conceptual domain $\mathrm{A}=$ conceptual domain $\mathrm{B}$, vice versa. In that sense, the copywriters have recorded or achieved something remarkable with this metaphorical fabrication. The advertisers have succeeded in engaging the audience in critical thinking as stated earlier. It is imperative to quickly argue that so many people are not interested in ads, except such persons are encouraged to do so (Cook, 2001). That orientation seems to have influenced the copywriters to stimulate the audience with a common metaphor. On the one hand, if the advertisers claim is that Black is Guinness; then, Black is seen as the target domain that shares some characteristics of Guinness. On the other hand, if it means that Guinness is Black, then, Guinness is presented as sharing some tenets of Black. Advertisers have created a parallel in the ads by inducing what is in Guinness to Black, and what is in Black to Guinness. Thus, the publicists have enticed recipients to both the communication information and the product's consumption. 
From a contextual perspective, the notion of Black, as history reports, correlates the Black people all over the world (Stubbs, 1978; Wilson, 2011). Notably, in the US, where the African-American consciousness movements stemmed, in terms of the cultural aesthetics, intra-racial diversity, and personal black beauty judgments, were reckonable events (Ortega, 2018). These gave rise to the affirmation We are Black and beautiful, and Black is beautiful. The movements, as Taylor (2016) manifests, originated from Christian bodies, confronting horrors and brutality of the White people stakeholders, and aggressively agitating freedom of expression for the cultural treasures of the Black community (Oden, 2007). Given this demandcum-information, Guinness, the Irish company, seizes the opportunity to promote Black, correlating with the black content of the beer, as a terminology of visibility (Seleoane, 2008; Webley, 2015). Thus, Black is beautiful becomes a marketing model of Guinness to seduce potential customers to consumption. Upon this backdrop, Guinness lures the African-American feelings upon the Nigerian potential customers, coaxing individuals to fraternize with African-American qualities as much as to the Guinness stout.

Furthermore, one observes the cleverness of the metaphorical Guinness ads in the manners that the publicists evoke the color of Black, interconnecting some relationships between Guinness contact appearance and potential Nigerian customers. The goal of evoking Black as an appeal is to elevate the Black people of the human qualities in the individuals. In other words, the Guinness ads utilize the concept of Black as possessing similar characteristics with the White counterparts. As the ads are fundamentally-Nigerian focused, the mission might be for Nigerians to look at themselves as people who are not inferior to the White people. One needs to comment here that Nigerians are Black people (Gordon, 1997; Abraham, K., 2003). However, some European expatriates are in Nigeria to function in some critical

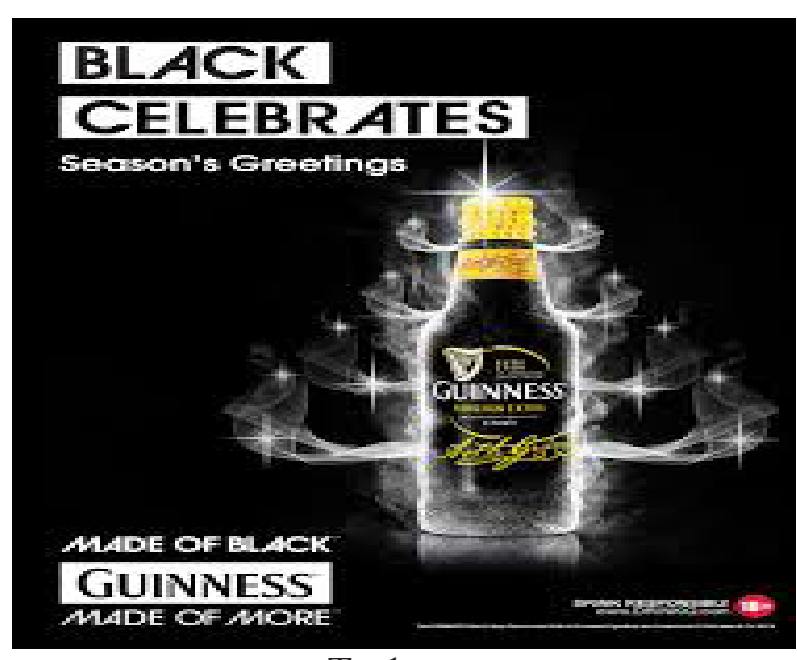

Tx.1 areas of industries. Thus, Guinness employs Black to stimulate that Nigerians that individuals are human beings with similar qualities as the White people. Anyway, drinking Guinness stout as the white people do is a proof of equality.

In the first clause, Black celebrates, of Tx.1 for instance, Guinness is the source domain and Black is the target domain. The second clause, made of 
Black, indicates Black as the source domain while Guinness is the target domain. There is a sort of breakthrough for advertisers against the public here. Confusion is effectively created as a thought provoking facility. The inventive exercise could take time before readers decode the meaning. However, in all, the ads have accomplished their imaginative missions by creating awareness that persuades consumers not only to the ads but also to Guinness, the Black. This metaphorical creativity is not only fascinating but it is also highly educative.

Contextually, celebration is a cultural norm among the people. Having interconnected this study as a support for the Black people's consciousness (Cone, 1975), one might argue that Black celebrates pinpoints freedom from: the paucity of Black characteristics of maginalization, race-specific downplaying decisions, and modern slave-holding society (Kaunda, 1966; Jackson, 1972; Biko, 1978a). The emergency of the Black identity, as a glide from exploitation and oppression, could inform the organization of ceremonies in different places like their master-counterparts (Dolamo, 2017; Bicknell, 2017). The Black people are independent with legal rights to solemnize their social rituals and religious rites. Tx.1 campaigns entertainment, gratitude, and freedom of social gathering against the White oppression. Celebration seems the results of the struggle for Black emancipation.

In another parlance representation, Black, is also personified. The concept translates to mean that Guinness $=M r$. Black. The ad realizes the humanness of Black in the communication. Moreover, Tx.1 addresses Black as bearing some human characteristics and performing functions of man, signified as Black celebrates. Celebration seems a function of man. Animals (lower animals) may not be known to celebrate. Even if they do, everybody may not understand its modus operandi except for scientists whose focus of study is the animal kingdom. One might also consider Black as being animated to function in alignment with human beings. People tend to throw in parties when they have accomplished great things in life, and the celebration will involve more than one person. It takes a group of people to celebrate achievements of relatives. Guinness, Mr. Black, usual setting is parties. Sincerely, a keen observation shows that anywhere people are drinking Guinness, even in the beer parlor arena; the place is agog with laughter as if some people are celebrating a particular attainment in life. Guinness serves as the target domain in the ads, adopting the manners of the consumers, source domain, in order to behave as such. The advertising professional endows the festive season attitudes of the public on Guinness.

The operational landscape of Tx.2 is similar in nature to Tx.1, where the communicator adopts concept 'dance' to characterize the Guinness and Black connection. Tx.2 reveals that Blackdances to a different beat. That clause demonstrates a classical function with unique parameters. The application of a noun group different beat is to portray Guinness as a classical drink that can be compared to a canon in the text of literary genre. It seems to the author that a relatively constructed comparison 


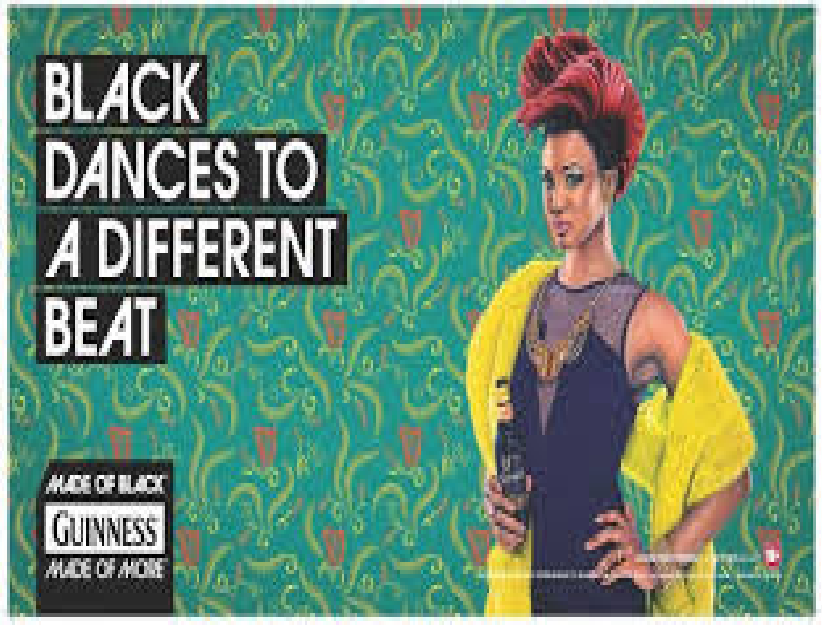

Tx. 2

strongly classifies Guinness as a different phenomenon from other beers. The metaphor decorates Guinness as a dancer. A dancer (e.g. a woman dancer) does not just come out in the public sphere and begins to perform. There are places where a dancer performs. She dances in a party or a theatre house where a throng of people fastens their eyes on her. The nature of her profession informs the manner of her appearance in the public. Such dancer is fashionable and attractive to impel her audience. The individual ought to be skillful in her performance so that there will be value for what the audience has paid for. Besides, her present performance should be a force to be reckoned with next time. A dancer is glittered while on stage with special dancing steps. These dynamisms are factor that will impress her spectators to appreciate her activities and hail the individual. She may momentarily become famous. The ovation of her popularity may be so loud to a considerable extent where the public may not intend to live their lives without the dancer's dancing steps. These are the attributes that Guinness, Mr. Black personified, has adopted from the source domain as 'he' intends to dance in the public glare in order to influence the target audience.

Interlocking Blackdancestoadifferentbeat with theUSconsciousnessmovements (Biko, 1978b; Du Bois, 1982) might yield uniqueness of the Black race. In this case, this ad initiates a departure from the way of suppressing the Black under a particular overwhelming cultural rule, political hegemony and an excessive will-power of supremacy to a condition of a liberty of social and political dimensions, legitimized by the constitution of liberality (Jackson, 1970; Langa, 1975. Du Toit, 2008). The slogan could also mean a change in approaching personal disciplines to a life of commitment, which produces meaningful resources. Indirectly, Guinness of the Irish background supports the black people, seemingly intervening between the White and Black.

One might elucidate that Guinness appears to be protesting against the horrible actions of the White, seeking the pitfall, intolerance, and disintegration of the Black. The ad sensitizes the Black to embrace, uphold, and appreciate their cultural identity against the narrative of invisibility (Jackson, 1970).

Furthermore, dances to a different beat refers that Black does its own thing as it decides, against the White's standards that construct Black's way of life (Nyerere; 
1968; Langa, 1975 19; Marsh, 2013). For instance, a woman dressing in an elegant gown appears as an expression of appeal to readers in order to drink Guinness and nothing else. Dance is a form of lifestyle. The woman posture in the ad depicts a sophisticated individual at a social occasion, who probably classifies herself by dancing to a different beat. Exceptionality, as Tx.2 claims, should lead to the consumption of a Guinness stout.

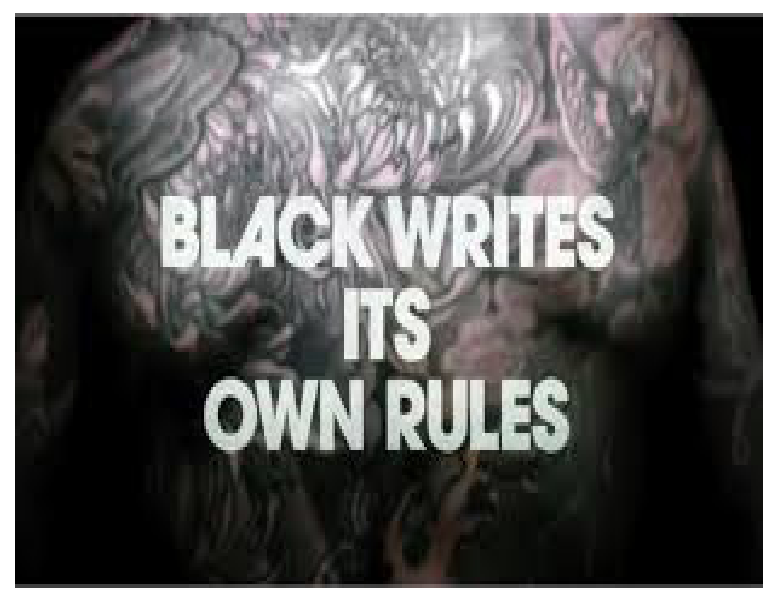

Tx.3

Tx.3 communicates that Black writes its own rules. At this juncture, it is worthwhile to note that the source domains are implicit by hanging in the air. The communicative elements are abstract underlying domains that demand critical thinking to unravel the meaning. The source domains, as Tx.3 establishes, are hidden entities. From this perspective, the implicit domains in which Guinness intermingles with might be a writer, a lawyer, policy maker, a lawmaker or a king. A writer has variegated functions including crafting a good piece of ideas in texts. Among other things, a lawyer defends his client and when advancing in the profession that individual may have an opportunity to become a judge of a state, deciding critical and intricate matters. A policy maker may chart a management course for a company or an institution. Every democratic country has a viable institutionalized national assembly where the constitution of the country is defended; more laws on how to further govern the country are promulgated as published in the country's gazette.

To a great extent, Black writes its own rules lays emphasis on the lexeme, own. Own carries some weights, underscoring a kind of emphasis in the declarative clause. Thus, the word, own, means that Black is no longer governed by draconian laws of others (Manganyi, 1973; Magaziner, 2010). Black rather does things the way 'he' pleases. Tx.3 promotes the origination of Black against supremacy of the leadership of the Whites. Going back to the cultural movement of the 1960's, one of the key factors is the appreciation of the Black past as a worthy legacy (Maloka, 2002; Mngxitama, Alexander \& Gibson. 2008). By implication, the Black's peculiar matter is a cultural revolution of pride and power. This idea describes the inspiration of the Black cultural pride even in the contemporary time.

One could make a choice domain for Guinness out of the entire contingency. The analyst adapts the position of a king as the referential Black in order to interpret 
the intermingled possibilities. Thus, Guinness dominion, in the point of view of the interpreter, represents the head in the brewing industries where other beers give special reference to Guinness in 'his' autonomous kingdom. The domineering role that Guinness plays in the world of beer should earn 'him' respect. As a king dresses gorgeously, being a symbol of royalty, so also is the appearance of Guinness, King Black, in the midst of 'his' entourage. The creation of Guinness as a king, probably, is to persuade the ad's recipients to identify with the traits of a king. Consequently, a king is known not to be controlled by others but his sole responsibility is to dominate and control others with the enormous power that is traditionally given or constitutionally apprehended (Kessler, n.d.).

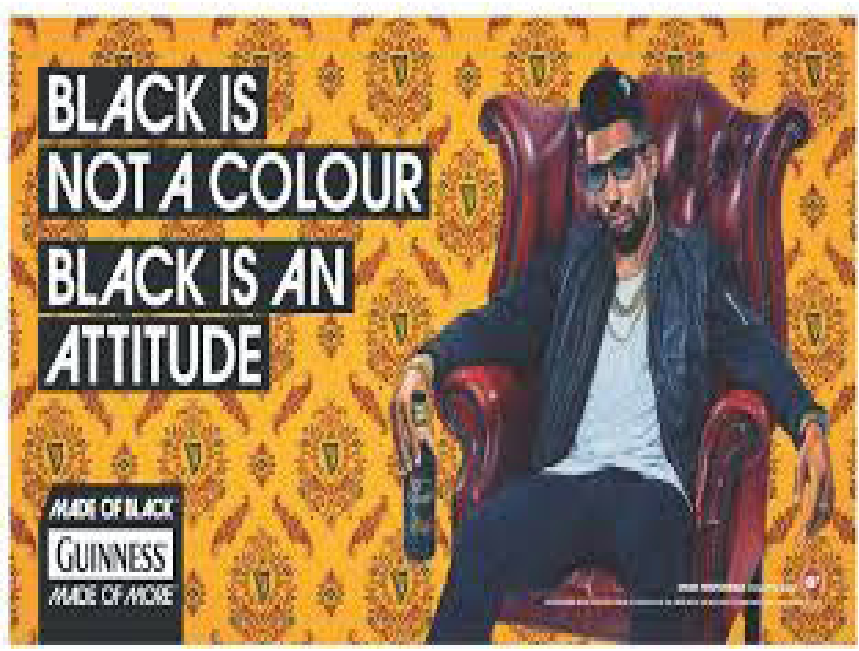

Tx.4

There are two distinct clauses in Tx.4. The first clause is Black is not a color. The second is Black is an attitude. These two clauses have distinctive variations, located in their finites. Clause one indicates a form of negative polarity is not while positive polarity is is typified in clause two. Appreciating these finites from a semantic abstraction, ordinarily, pinpoints the finite in clause one to probably negate an unknown course. Clause two reveals the unknown (hidden) course in clause one. However, the semantic value indicates a form of retrogression when one considers the messages of the clauses as a single piece. Clause two, Black is an attitude tends to negate Black is not a color, which is quite different from its syntactic value. Moreover, the two clauses' source domains, that is, color and an attitude embed another distinction. These source domains do not have any form of relations at all because a color and an attitude are separate entities. The advertising practitioner employs the source domains to differentiate what Black is, and what Black is not. The career metaphor, Black, in relations to Guinness distinguishes what Guinness should be to the audience from what Guinness should not be to potential customers. Earlier in this paper, the author has classified the possibilities of meaning that Black can entail. Among the arrays are: dark skin, power and control, color, mystery, darkness, end of an era, and seduction. Tx.4 replicates such elements in the textual constructs. 
The revelation of the metaphorized Black means an attitude. The attitude in the structural arrangement of the advertising frame is a probable connection to seduction. The pictorial indication (though out of the study's scope) shows a young man sitting down in an armchair and holding a bottle of Guinness in his hand. One could interpret the relaxation mood of the young person, as an appeal, influencing readers to drink the Guinness stout, Mr. Black. By implication, it is not the only attitude that Guinness ad represents; the ad represents an idealized stable behavior, as related to the other ads. The Black's attitude ductility, based on the ads to the following characteristics of beauty, merry-making, dancing, celebration, kingship, confidence, self-importance and fashionable, rejects all forms of negativism. Attitude fraternizes itself with precise individuality.

Moreover, Black is an attitude is paradoxical in this message. This appeal connotes a historical report that: Blackness cannot represent the pigmentation of one's skin but an attitude (Woods, 1987). That is a state of mind, identified with Black man's struggle against oppression. This has a reference point as 'Blackman you are on your own' (Snail, 2008). One might recapitulate that Black is a color of matchlessness. However, among Nigerians, the publicist invites Nigerians to consider Black as a personal lifestyle, involving self-confidence, distinction, pride, power, and success to negate the White's perception about the Black.

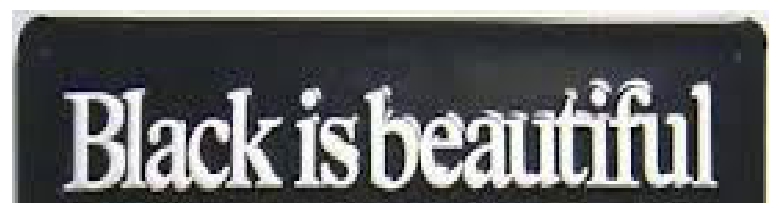

The nature of mapping shown in Tx.4 between the literal and figurative items is analogical, as exemplified in the two clauses. Their comparisons have brought the analysis to

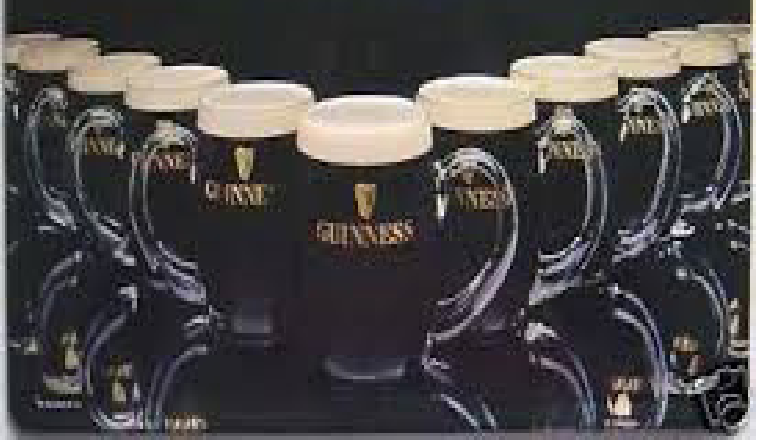

Tx. 5 a level of abstractions that conveys common relations between the target domain and the source domain (i.e. Black $\neq$ a color; Black = an attitude); and clause one and clause two (i.e. Black is not a color; Black is an attitude). The author observes the negligence of similarities in color and Black; and acceptance of similarities of attitude and Black. Black rejects color discrimination and accepts positive attitudes. In a comparative form, the advertising practitioner paints two different pictures in Tx.5 and Tx.6 respectively. Tx.5 reads Black is beautiful. Black is beautiful seems to contain an implicit source domain. As people appreciate Black, as being goodlooking, attractive and stunning; the advertiser pinpoints that the same attitude should 
be channeled toward drinking Guinness. This seems the rationale interpretation of Black is beautiful to the patronages of the Guinness stout.

Falling back to the slogan Black is beautiful in the US in the 1960s, the original context of Tx.5 explicates that the Black people are beautiful in all ramifications of life. The beauty, in Guinness' essence, goes beyond the color splendor. The beauty rather connects the entire culture and life patterns of the entire Black communities (Biko, 1978b). Guinness deploys the Black is beautiful slogan as a strategy to turn the frequently pejorative connotation of the English word, Black, upside down, projecting Black as an invaluable entity. As a result, the Black people should be proud of their natural identity and personality, of whom these individuals are original (Taylor, 2016). They should be proud and happy that they are not white; and they should not attempt or imitate to be white. In that regard, the Black should not try to be White, using hair straighteners and skin lighteners as Michael Jackson did. The Black people should imitate some icons of the Black art icons such as James Brown, Hoyt Fuller, Mohammed Ali, Amiri Baraka, Flip Wilson.

Beauty is one of the characteristics of a lady. This idea is deduced when one connects the characteristic of Black is an attitude with Black is beautiful. As most men may appreciate a beautiful lady, the advertiser pinpoints that the same attitude should be channeled towards Guinness.

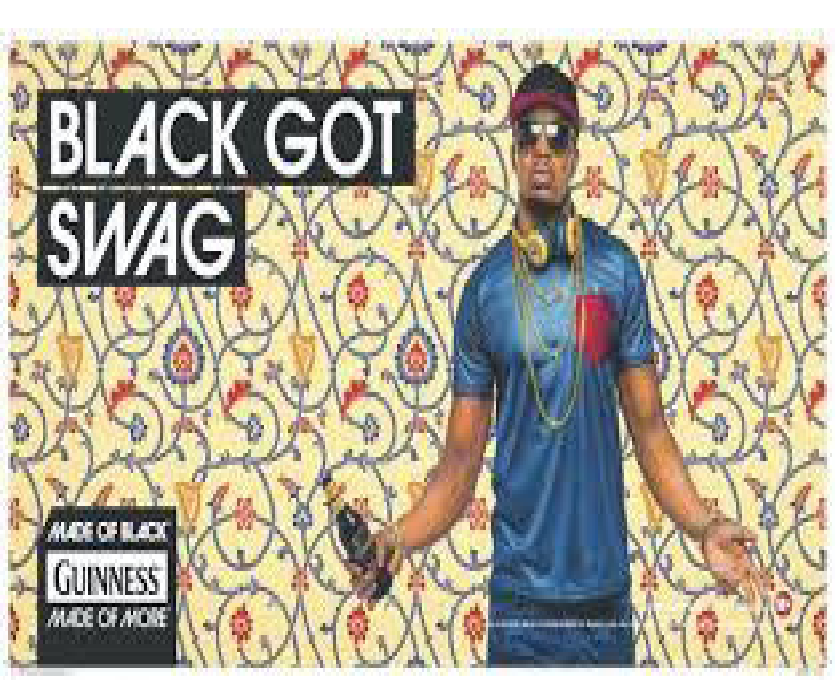

Tx.6

The advertiser personifies Guinness in Tx.6 thus: Black got swag. Literally, the finite has is omitted in the textual construction because the linguistic component links the past to the present. The clause ought to be cast correctly thus: Black [has] got swag else the statement will be suggested as referring to the past. Notwithstanding, the study recognizes and appreciates the syntactic rule initiated in the ad frame, i.e. Black got swag. One of the attitudes that the target domain, Guinness, represented is swag. Swag cannot be a feature of Guinness but a person. The communication hides a young person, who is the source domain in the text, yet, indicated as a picture. The author could also perceive swag as a short form of swagger. Probably, the analyst might translate swag to readers as confidence, self-worth and self-confidence. The 
term swag seems informal. Language users deploy swag, commonly and popularly, among young people, young musicians and other artists.

Constructing and exemplifying Black got swag in the African-American perspective could also yield some meaningful results. Black got swag is a present tense in colloquial US English. This is because interactants understood the unspoken word, has, in the colloquial speeches. In respect to that one might possibly comment that got swag is an allusion to the celebrated dairy advertising campaign slogan, got milk, meaning Have you got milk? Thus, variations of this phrase have been ubiquitous in the US in many contexts since it was first introduced in 1993. For example, someone might arrive at a party with a six-pack of Guinness stout and a kind of joke might come up to say, Got Guinness stout?

The ad also confirms the veracity of Black got swag as a reality, supported with the exhibition of theimage of a young person, who appears to listen to music. The individual wears a number of fashionable materials including baseball cap, a pair of glasses along with electronic air piece, and jewelry with a bottle of Guinness in his hand. The individual even sags the pair of trousers with an appearance of youthful exuberance.

The young man's general appearance would not be much out of place when one connects such to events on the streets of New York. The Guinness advertiser seems to be creating an association between bling-wearing African-American in the US and an Irish beer in Africa. A denotation that Nigerian potential customers, as Tx.6 connotes, must adopt. Once again, a reader who has swag is not only confident; the individual is self-assured and sexy. In addition, someone with swag might write his own rules and dance to different beats. By Implication, one might comment that swag among the Black people are often associated with wearing bling, and jewelry such as the young man in this ad demonstrates. Swag is somewhat synonymous with attitude, though attitude might have a more aggressive connotation. Nevertheless, the young man in this ad illustrates attitude and swag.

The metaphorized 'swagness' demonstrated in the person is a persuasive strategy in the 'Guinnessian' interchangeability (Williamson, 2002) against consumers' natural decisions. Down below the ad, the publicist inscribes [Guinness is] made of Black and Guinness [is] made of more. These elliptical statements seem as the conclusion of the matter of Guinness. As much as the elliptical metaphors agree that Guinness is actually enormously appreciated in the contents of Black; Guinness also claims to give more benefits to consumers in terms of consumption better than any former experience.

\section{CONGLUSION}

The author has attempted the analysis of the selected ads of Guinness to show the strategy that advertisers adopt, utilizing Black to laud the image of Guinness. 
Such promotional goal aims at provoking recipients to consistent consumption. First, the six clauses of Black are declaratives. That means that the grammatical structures are statements employed to appeal to the public in solemn ways. The communications do not command the target audience to buy. The ads only construct systematized approaches to fraternize with and convince the people through their socio-cultural behaviors. Second, Black represents the stout in so many forms such as sophistication, fashion, self-confidence, kingship, dominion, celebration, and beauty. The images of Black, which are source domains are implicitly metaphorized as images of Guinness. The implications are that Guinness adopts Black as its source domain; and other attributes from the figurative domains in texts are indirectly labeled as Black.

Third, the Guinness stout ads are paradoxical. This is owing to the fact that many African-Americans want to emphasize their connection with African roots. Nonetheless, Guinness rather deploys these ads as an appeal, inviting African, and especially Nigerians, to connect to African-American characteristics. These advertising campaigns seem an answer to someone's request: Why are you drinking the Irish beer in Nigeria?" In corollary, some of the responses are: Nigerians have attitude; Nigerians write their own rules; Nigerians dance to a different beat; and Nigerians got swag. This refers that Africans, Nigerians, and the Black people do whatever please them without the interference or disturbance of any foreign supremacy. Therefore, Nigerians as well as Africans have the liberty to drink Guinness if they choose to. Anyway, Guinness is Black; Africa is Black; and Guinness is African.

The metaphorical expressions prepare, address and present Guinness as a jewel that everyone should adore. That tenet purposely motivates Nigerian consumers in order to appreciate the status and increase the consumption of Guinness in the beer competitive market. Besides, this ad could serve as a support for all stakeholders that frown at and cry against racism of any degree. Scholars could still conduct further researches on these ads by investigating the relationships between the texts and images. Also, researchers could analyze the pictorial representations in the ads alone in order to advance their metaphorical meanings. From a linguistic perspective, language is about choice. The choice demonstrates the mode of communication types which invariably dictates a way of making meaning. Therefore, the choice of Black that Guinness propagates in the communications seems a way of exhibiting a kind of style in writing and people's culture in order to communicate ideas. Guinness' style could sensitize students, writers and researchers to construct an individual style of addressing diverse readers' cultural treasures. 


\section{REFERENCES}

Abraham, K. (2003). Politics of Black Nationalism: From Harlem to Soweto. New Jersey, NJ: Africa World Press, Inc.

Adedun, E. (2006). Literary elements as communicative strategies in advertising. Literature, Language and National Consciousness: A Festschrift of Theo Vincent, 130-36.

Batra, R., Myers J., and Aaker D. (1995). Advertising management. New York: Pearson.

Bicknell, J. (2017). Paul C. Taylor. Black is Beautiful: A philosophy of black aesthetics. Philosophy in Review, XXXVII (4), 172-173.

Biko, S. (1978a). Black consciousness and the quest for true humanity. In A. Stubbs (ed.), I write what I like, pp. 87-98. London, GB: The Bowerdean Press.

Biko, S. (1978b). White racism and black consciousness. In A. Stubbs (ed.), I write what I like, pp. 61-72. London, GB: The Bowerdean Press.

Bittner, J. (1989). Mass communication: an introduction. New Jersey: Prentice-Hall, Inc.

Black, M. (1979a). How metaphor works. In Ortony, A. (ed.) Metaphor and Thought. Cambridge: Cambridge University Press. 19-43.

Black, M. (1993). More about Metaphor. In Ortony, A. (ed.) Metaphor and Thought. Cambridge: Cambridge University Press. 19-41.

Bloor, T. \& Bloor, M. (2004). The functional analysis of English. Great Britain: Hodder

Bloor, T. \& Bloor, M. (2013). The functional analysis of English. Abingdon, Oxon: Routledge.

Bounegru, L., \& Forceville, C. (2011). Metaphors in editorial cartoons representing the global financial crisis. Journal of Visual Communication, 10, 209-229.

Brierley, S. (2002). The Advertising Handbook. London: Routledge.

Chandler, D. (2006), Media semiotics. Retrieved on 23 $3^{\text {rd }}$ October, 2010 from http:// www.scribd.com/doc/205815385/14165439-Media-Representation- $\quad$ D a v i d Chandler\#scribd

Churcher, M. A. (2009). Stokely carmichael, "black power" (29 October 1966). Voices of democracy 4, (P. 132-148). Retrieved on $10^{\text {th }}$ June, 2015 from http:// voicesofdemocracy.umd.edu/wp-content/uploads/2010/07/churcher-carmichael. pdf

Cone, J. H. (1975). God of the Oppressed. New York, NY: Seabury Press.

Cook, G. (2001). The discourse of advertising. New York: Routledge.

Cross, W., Parham, T., \& Helms, J. (1991). The stages of Black identity development: Nigrescence models. In R. L. Jones (ed.), Black Psychology (3rd ed.), pp. 319-338.

Dolamo, R. T. (2017). The legacy of Black Consciousness: Its continued relevance for democratic South Africa and its significance for theological education. HTS 
Black: A persuasive metaphor in Guinness stout's ... - T. Olaiwola Dalamu

Teologiese Studies/Theological Studies 73(3), a4587. https://doi.org/10.4102/hts. v73i3.4587.

Dalamu, T. O. (2018). Advertising communication: Constructing meaning potential through disjunctive grammar. Anagramas: rumbos y sentidos de la comunicación 17 (33), 73-104.

Dijk, T. A. van (2008). Discourse and power. New York, NY: Palgrave Macmillan.

Du Bois, W. E. B. (1982). The souls of Black folk. New York, NY: Signet Classic.

Du Toit, C.W. (ed.) (2008). The legacy of Stephen Bantu Biko. Pretoria, SA: UNISA.

Deutsch, E., Doberstein, E., \& White, K. V. (2008). Stereotypes, diversity, and effects on academic advising. The Mentor: An Academic Advising Journal. Retrieved on 6th November, 2014 from http://dus.psu.edu/mentor.

Dyer, G. (2005) Advertising as communication. London: Routledge.

El Refaie, E. (2003). Understanding visual metaphors: the example of newspaper cartoons. Visual Communication, 2, 75-95.

El Refaie, E. (2009). Metaphor in political cartoons: Exploring audience responses. In Forceville, C. \& E. Urios-Aparisi (eds.), Multimodal Metaphor (pp. 173-196). Berlin: Mouton de Gruyter.

Forceville, C. (1996). Pictorial metaphor in advertising. London and New York: Routledge.

Forceville, C. (2000). Compasses, beauty queens and other PCs: Pictorial metaphors in computer advertisements. Hermes, Journal of Linguistics, 24, 31-55.

Forceville, C. (2005). Visual representations of the idealized cognitive model of anger in the asterix album La Zizanie. Journal of Pragmatics, 37, 69-88.

Forceville, C. (2006). Non-verbal and multimodal metaphor in a cognitivist framework: Agendas for research. In G. Kristiansen, M. Achard, R. Dirven, \& F. Ruiz de Mendoza Ibàñez (eds.), Cognitive linguistics: Current applications and future perspectives (pp.379-402). Berlin: Mouton de Gruyter.

Forceville, C. (2007). Multimodal metaphor in ten Dutch TV commercials. Public Journal of Semiotics, 1, 19-51.

Forceville, C. (2008). Metaphor in pictures and multimodal representations. In R.W. Gibbs (ed.), The Cambridge Handbook of metaphor and thought pp 462-482. Cambridge: CUP.

Forceville, C. (2013). The strategic use of the visual mode in advertising metaphors. In E. Djonov \& S. Zhao (eds.), Critical Multimodal Studies of Popular Culture, pp. 55-70. New York, NY: Routledge.

Gayle, A. (1971). The Black Aesthetics. Garden City, NY: Doubleday.

Gee, J. P. (2011). An introduction to discourse analysis: Theory and Method. New York, NY: Routledge. 
Geis, M. (1982). The language of television advertising. London and New York: Academic Press.

Gieszinger, S. (2001). The history of advertising language. Frankfurt: Peter Lang GmbH.

Gentner, D. \& Bowdle, B. (2008). Metaphor as structure-mapping. In R.W. Gibbs (ed.), The Cambridge Handbook of metaphor and thought pp 115-116, Cambridge, UK: CUP.

Goldman, R. (1992). Reading ads socially. New York, NY: Routledge.

Gordon, L. R. (ed.) (1997). Existence in Black: An anthology of Black existential philosophy. New York, NY: Routledge.

Glucksberg, S. (2003). The psycholinguistics of metaphor. Retrieved on 7th May, 2014 fro http://www.colorado.edu/linguistics/courses/LAM5430/More5430e- reserves/ PSYCHOLING METAPHOR.pdf.

Halliday, M.A.K. (1995). An introduction to functional grammar. Great Britain: Arnold.

Halliday, M.A.K. \& Matthiessen M. I. M. (2004). An introduction to functional grammar. Great Britain: Hodder Arnold

Halliday, M.A.K. \& Matthiessen M. I. M. (2014). Halliday's introduction to functional grammar. Abingdon, Oxon: Routledge.

Hermerén, Lars (2001). English for sale: A study of the language of advertising. Lund: Lund University Press.

Honeck, R. (1996). Introduction: A figurative language and cognitive science - past, present and future. Metaphor and symbolic activity 11, 1 (p. 1-16). Mahwah, New Jersey, NJ: Lawrence Erlbaum Associates, Publishers.

Imre, A. (2010). Metaphors in cognitive linguistics. Eger Journal of English Studies, X, $71-81$.

Jackson, G. (1970). Soledad Brother: The prison letters of George Jackson. Harmondsworth, GB: Penguin.

Jackson, G. (1972). Blood in my eye. New York, NY: Black Classic Press.

Kaunda, K. 1966. A humanist in Africa. London, GB: Longman.

Kessler, V. (n.d.). Leadership and power. Retrieved on $13^{\text {th }}$ July, 2016 from Saylor.org, 1-24; https://www.saylor.org/site/wp-content/uploads/2013/01/BUS209-4.2LeadershipandPower.pdf

Koschnick, W. (1995). Dictionary of marketing. Aldershot: Gower.

Kövecses, Z. (2005). Metaphor in culture: Universality and variation. Cambridge, Mass: CUP.

Kovecses, Z. (2010). Metaphor: A practical introduction. New York, NY: OUP.

Lakoff, G. \& Johnson, M. (1980). Metaphors we live by. Chicago: University of Chicago Press. 
Langa, B. (1975). Black Consciousness and the Black community. SASO Newsletter $5(1), 9-12$.

Leech, G. (1966). English in advertising: A linguistic study of advertising in Great Britain. London: Longman.

Livingston M., Pierce L., \& Gollop-Brown, L. (2013). Not all Blacks are African American: The Importance of viewing advisees as individuals in a culturally Mosaic context. Retrieved on 15 th January, 2015 from https://dus.psu.edu/mentor/2013/08/ blacks-advisees-culturally-mosaic-context/.

Maalej, Z. (2001). Processing pictorial metaphor in advertising: a cross-cultural perspective. Academic Research, 1, 19-42 [Sfax, Tunisia].

Magaziner, D. (2010). The law and the prophets: Black Consciousness in South Africa, 1968-

977. Athens, OH: Ohio University Press.

Malcolm X. (1965). The autobiography of Malcolm X. New York, NY: Grove.

Maloka, E. (2002). Towards the African Renaissance: The African Union and the New Partnership for Africa's Development (NEPAD). Report on the 9th Conference of Africanists, Moscow, Russia.

Manganyi, N. C. (1973). Being-Black-in-the-world. Johannesburg, SA: Spro-Cas and Ravan Press.

Marsh, R. (2013). Understanding Africa and the events that shaped its destiny. Pretoria, SA: LAPA Publishers.

Martín de la Rosa, V. (2009). The role of pictorial metaphor in magazine advertising. Revista Alicantina de Estudios Ingleses 22, 167-180.

Messaris, P. (1997). Visual persuasion: The role of images in advertising. Thousand Oaks, CA: Sage.

Mngxitama, A., Alexander, A., \& Gibson, N. C. (2008). Biko lives! Contesting the legacies of Steve Biko. New York, NY: Palgrave.

Myers, K. (1986). Under stains: The sense and seduction of advertising. Surrey, GB: The Gresham Press.

Myers, G. (1994). Words in ad. New York: Oxford University Press.

Nixon, S. (1996). Hard looks: Masculinities, spectatorship and contemporary consumption. New York, NY: St. Martins.

Nyerere. J. K. (1968). Ujamaa: Essays on socialism. Oxford, GB: Oxford University Press.

Oden, T. C. (2007). How Africa shaped the Christian mind. Downers Grove, IL: Intervarsity Press. 
Ortega, M. (2018). Black is beautiful: A philosophy of Black aesthetics by Paul C. Taylor. Critical Philosophy of Race, 6(2), 287-292.

Ortony, A. (1993). The role of similarity in similes and metaphors. In A. Ortony (ed.), metaphor and thought, pp. 242-356. New York, NY: CUP.

Pityana, N. B. (1972). What is Black Consciousness? In M. Motlhabi (ed.), Essays on Black theology, pp. 37-43. Johannesburg, SA: UCM.

Robinson, H. (2012). Relationalism versus representationalism: How deep is the divide? The Philosophical Quarterly, 62, 248, (p. 614-619). DOI: 10.1111/j.14679213.2012.00060.x. Retrieved on 6th November, 2014 from http://onlinelibrary. wiley.com/doi/10.1111/j.1467-9213.2012.00060.x/abstract.

Ricoeur, P. (1977). The rule of metaphor: Multi-disciplinary studies of the creation of meaning in language (trans. R. Czerny el al.), Toronto: Toronto University Press.

Rosenberg, J. M. (1995). Dictionary of Marketing and Advertising. New York, NY: Wiley \& Sons.

Seleoane, M. (2008). The development of black consciousness as a cultural and political movement (1967-2007). In C.W. du Toit (ed.), The legacy of Stephen Bantu Biko, pp. 15-56. Pretoria, SA: UNISA.

Schultz, D., \& Barnes, B. (1995). Strategic advertising campaigns. Lincolnwood, IL: NTC Books.

Snail, M. (2008). The black consciousness movement in South Africa: A product of the entire black world. Historia Actual Online, 15, 51-68.

Stubbs, A. (ed.) (1978). I write what I like. London, GB: The Bowerdean Press.

Stern, J. (2008). Metaphor, semantic and contetext. In W. Gibbs Jr. (ed.), Metaphor and thought, 262-79. Cambridge, GB: Cambridge University Press.

Strommer, D. W. (2001). Advising across cultures. The Mentor: An Academic Advising Journal. Retrieved on 17 September 2015 from http://dus.psu.edu/mentor.

Svaziene, L. (2010).The persuasive effect of metaphor in advertising. . Retrieved on $5^{\text {th }}$ August, 2014 from http://vddb.library.lt/fedora/get/LT-eLABa-0001:J.04 2010 IS SN_16488776.N_2_27.PG_111-115/DS.002.1.01.ARTIC.

Taylor, P. C. (2016). Black is beautiful: A philosophy of Black Aesthetics. New York, NY: Wiley Blackwell.

Tomaskas G. (2014). Media representation theory. Retrieved on $10^{\text {th }}$ April, 2015 from http://www.slideshare.net/Tomaskas/media-representation-theory

www.empower-yourself-with-power-psychology.com.

Thompson, G. (2004). Introducing functional grammar. Great Britain: Hodder Arnold.

Thompson, G. (2014). Introducing functional grammar. Abingdon, Oxon: Routledge. 
Webley, Q-A. (2015). My Black is Beautiful: A study of how hair is portrayed in children's and young adult literature. HIM 1990-2015. 1753. Retrieved on 21 March 2020 from https://stars.library.ucf.edu/honorstheses1990-2015/1753.

Wicke, J. (1988). Advertising fictions: Literature, advertisements and social reading. New York, NY: Columbia University Press.

Wierzbicka, Ann (2006). English: Meaning and culture. Oxford, GB: Oxford University Press.

Wilson, L. (2011). Steve Biko. Johannesburg, SA: Jacana.

Woods, D. (1987). Biko. Revised and updated. New York, NY: Penguin. 